Special Section: The economies, ecologies and politics of social forestry in Indonesia Research Article

\title{
Bridging social forestry and forest management units: Juxtaposing policy imaginaries with implementation practices in a case from Sulawesi
}

\author{
Tajuddin Tajuddin ${ }^{1,2}$, Supratman Supratman ${ }^{3, *}$, Darmawan Salman ${ }^{4}$, Yusran Yusran ${ }^{3}$ \\ 1 Doctoral Student at Universitas Hasanuddin (UNHAS), Makassar, Indonesia; tajuddin.agathis@gmail.com \\ 2 Production Forest Management Agency Regional XIII Makassar, Directorate General of Sustainable \\ Management of Production Forest, Ministry of Environment and Forestry \\ 3 Laboratory on Forest Policy and Entrepreneurship, Faculty of Forestry, Universitas Hasanuddin (UNHAS), \\ Makassar, Indonesia \\ 4 Department of Social Economics, Faculty of Agriculture Hasanuddin University (UNHAS), Makassar, \\ Indonesia \\ * Corresponding author: supratman.unhas@gmail.com
}

\begin{abstract}
As the priority forestry development programs in Indonesia in recent years, Social Forestry policies (SF) and Forest Management Units (FMU or $\mathrm{KPH})^{1}$ still indicate low performance. The SF program in particular, is dependent on the role of the KPH as an institution in realizing its expected goals. Using the theory of bureaucratic politics, this article presents the implementation of the SF program under the KPH system and how both programs can mutually support or inhibit the development of the other. The research was conducted using policy content analysis in the implementation of SF and KPH programs by applying interview methods, questionnaires and field observations that are presented both qualitatively and descriptively. We find that the development of SF cannot be separated from the role of the KPH bureaucracy due to the absence of bureaucratic institutions at the site level. SF sites are located in KPH working areas and perform a central role in all aspects of SF management. However, SF programs are not clearly stated as one of the main tasks and functions of KPHs and the existence of $\mathrm{KPH}$ interests in realizing independence without special budget allocations for the development of SF are obstacles to its implementation. KPH also still face regulatory issues that have not fully supported KPH operations resulting in weak institutions and independence to governing hierarchies due to the strong influence of the bureaucracy at the central and provincial levels. On the other hand, the SF program is still perceived as a rival of KPHs in forest management areas and further suffer from rigid regulations that are difficult to apply, making it challenging for SF to support the objectives of KPH programming. Under these conditions, KPH tend to limit SF schemes, thus privileging specific different forestry partnership schemes that are anticipated to support the independence of the $\mathrm{KPH}$.
\end{abstract}

Keywords: Forest Management Units (FMU); Social Forestry; Bureaucratic Politics.

\section{Introduction}

The high dependence of people on forest resources and limited access to forest management activities has resulted in an increase in the movement of people demanding access to state forests in Indonesia (Edmunds et al., 2003; Muhajir et al., 2011; Soepijanto et al., 2013; Maryudi et al., 2015). This has also taken place alongside one of the most dramatic transformations in natural resource management policies in modern history with the emergence of devolution policies that allow some form of access for local communities (Edmunds et al., 2003). Social forestry (SF), as a form of devolution is also anticipated to simultaneously improve livelihoods and forest conservation (Maryudi et al., 2012; Schusser, 2013; Moktan et al., 2016). SF in Indonesia is a generic term for devolution of power from the state to local groups of citizens in order to manage forests and land

\footnotetext{
${ }^{1} \mathrm{KPH}$, or Kesatuan Pengelolaan Hutan 
that are under government authority. Since the 1980s SF has become a popular policy throughout Asia, Africa and, more recently Latin America (Thompson, 1999; Fisher, 1999; Suharjito, 2009; Cronkleton et al., 2013; Baynes et al., 2016; Gilmour, 2016).

Devolution of power is the cornerstone of SF governance (Schusser, 2013; Schusser et al., 2014; Baynes et al., 2016). In Indonesia, government attention to SF emerged in the form of allocating the benefits of forest resources as taking place in official policy since the amendment of Forestry Act No. 5 of 1967 to Act No. 41 of 1999 (Yasmi, 2008; Kartodihardjo et al., 2013). The spirit of guiding forest policy for community involvement emerged during the World Forestry Congress III in 1978, which has since helped to make the formal case for SF in Indonesia (Soepijanto et al., 2013). SF in Indonesian forest management takes shape in particular permitting schemes, including Community Forestry (HKm - Hutan Kemasyarakatan), Community Plantation Forest (HTR - Hutan Tanaman Rakyat), and Village Forest (HD - Hutan Desa) (Suharjito, 2009).

On the other hand, the broader paradigm of forestry development in Indonesia is more oriented towards economic development, and due to the historical influences of Indonesia's political economy, has resulted in a strong licensing system and weak forest management at the site level, thus creating various contemporary challenges in the form of deforestation and forest degradation (Soepijanto et al., 2013; Setyarso et al., 2014; Kartodiharjo \& Suwarno, 2014). The KPH at the site level has recently become the core policy of forest management reform in the domestic forestry sector in Indonesia (Kartodihardjo et al., 2011; Raharjo \& Ulifah, 2014; Sahide et al., 2016). The KPH are envisioned as the main management approach anticipated to solve the problem of the lack of managers at the site level, addressing uncontrolled illegal logging and illegal trade, reducing forest degradation, resolving tenure conflicts, and overcoming economic decline in communities in and around the forests (Kartodihardjo et al., 2011; Rizal et al., 2011; Raharjo \& Ulifah, 2014; Ekawati, 2014b; Suwarno et al., 2016; Fisher et al., 2017).

Given that all forest areas in Indonesia are divided into KPH areas, the entire working area of SF for HKm, HTR, HD schemes and forestry partnerships is also managed under the KPH system (Kartodihardjo et al., 2011; Sahide et al., 2016). By applying a theoretical framework of bureaucratic politics, this article aims to analyze the relationship between SF and KPH programs and how the implementation of their agendas can mutually support or inhibit the development of their respective programs. To achieve this goal, we used content analysis to approach our examination of $\mathrm{SF}$ and $\mathrm{KPH}$ policies. The content analysis is derived from interview methods, questionnaires and field observations within SF and KPH design and implementation.

\section{Theoretical framework and context}

\subsection{Bureaucratic Politics}

In decision-making or action, all hierarchical and bureaucratic organizations have formal and informal structures (Wittrock et al., 1982; Hjern \& Hull, 1982). Formally, organizations act in accordance with constitutional mandates and established structures and do not make room for informal hierarchies (Krott, 2005; Diefenbach \& Sillince, 2015). However, because formal authority structures are rarely specified in full, there is room for informal institutions (Cooter, 1994; Ostrom, 2005). Therefore, the bureaucracy has two main objectives: the first, to formally provide public services that are oriented in accordance with the mandate provided; the second, they informally demand the interests of the organization to survive and expand the organization (Giessen et al., 2014). The theory of bureaucratic politics postulates that some bureaucratic organizations often have different and competing interests in the context of certain policies (Preston \& 'T Hart, 1999; Krott, 2005; Hubo \& Krott, 2010). Therefore, the theory of bureaucratic politics can be used to identify bureaucratic interests related to problems at various levels and explain behaviors that support or inhibit policy implementation (Sahide et al., 2016). In this study, the theory of 
bureaucratic politics was used to analyze the structure and mandate of the constitution that was formally established in the bureaucracy related to the KPH and SF programs (policy imaginary). Furthermore, the implementation of formal tasks and informal interests of bureaucratic organizations in the development of KPH and SF programs in the field were analyzed. Consequently, each of the bureaucracies within this dual goal (formal and informal) will have their own patrons. This patron shapes the formal structure hierarchically and is enhanced by interests in the bureaucracies when the political agenda is delivered. In this case the contestation of KPH and SF will lead to contestation of patrons among the bureaucracies.

\subsection{The concept of Social Forestry}

The definition of SF was first introduced by Westoby (1968) as a forestry activity that guarantees benefits of production to the community (Hakim, 2010; Das, 2015). SF can also be defined as the use of power and influence by local communities in the decision-making process and implementation of forest management including access and regulation of production (Maryudi et al., 2012; Dupuits, 2014). The Ministry of Environment and Forestry ${ }^{2}$ defines SF as "a sustainable forest management system implemented in state forests or forest rights concessions/customary forests, undertaken by local communities or legal customary communities as the main actors to improve their prosperity, ensure environmental balance and socio-cultural dynamics, in the form of village forest, community managed forests, people plantation forest, people forests, customary forests and forestry partnerships". The characteristics of each SF scheme are presented in table 1.

Table 1. Characteristics of various social forestry schemes

\begin{tabular}{|c|c|c|c|c|c|}
\hline \multirow[t]{2}{*}{ Aspects } & \multicolumn{4}{|c|}{ Community Forestry Schemes (in state forest areas) } & \multirow{2}{*}{$\begin{array}{l}\text { Customary } \\
\text { Forest }\end{array}$} \\
\hline & $\begin{array}{l}\text { Community Forest } \\
\text { (HKM) }\end{array}$ & Village Forest (HD) & $\begin{array}{l}\text { People Forest } \\
\text { Plantation } \\
\text { (HTR) }\end{array}$ & $\begin{array}{l}\text { Forestry } \\
\text { Partnership/ } \\
\text { Conservation } \\
\text { Partnership }\end{array}$ & \\
\hline Definition & $\begin{array}{l}\text { State forests in } \\
\text { which its uses are } \\
\text { primarily intended } \\
\text { to empower the } \\
\text { community }\end{array}$ & $\begin{array}{l}\text { State forests } \\
\text { managed by } \\
\text { villages and } \\
\text { utilized for village } \\
\text { welfare }\end{array}$ & $\begin{array}{l}\text { Plantation } \\
\text { forest in } \\
\text { production } \\
\text { forests built by } \\
\text { community } \\
\text { groups to } \\
\text { increase the } \\
\text { potential and } \\
\text { quality of } \\
\text { production } \\
\text { forests by } \\
\text { applying } \\
\text { silviculture in } \\
\text { order to ensure } \\
\text { the } \\
\text { sustainability of } \\
\text { forest }\end{array}$ & $\begin{array}{l}\text { Cooperation } \\
\text { between local } \\
\text { communities } \\
\text { and forest } \\
\text { managers, } \\
\text { license holders } \\
\text { of forest } \\
\text { utilization, rent } \\
\text { and use licenses } \\
\text { utilize forest } \\
\text { areas, or license } \\
\text { holders of } \\
\text { primary } \\
\text { industrial } \\
\text { business of } \\
\text { forest products. }\end{array}$ & $\begin{array}{l}\text { Forests that are } \\
\text { within the area } \\
\text { of management } \\
\text { by indigenous } \\
\text { peoples. }\end{array}$ \\
\hline
\end{tabular}

\footnotetext{
${ }^{2}$ MOEF regulation No. 83 of 2016
} 


\begin{tabular}{|c|c|c|c|c|c|}
\hline & & & resources & & \\
\hline Location & $\begin{array}{l}\text { Production forest } \\
(\mathrm{HP}) \text { and protected } \\
\text { forest }(\mathrm{HL})\end{array}$ & $\begin{array}{l}\text { Production forest } \\
\text { (HP) and protected } \\
\text { forest }(\mathrm{HL})\end{array}$ & $\begin{array}{l}\text { Production } \\
\text { forest (HP) }\end{array}$ & $\begin{array}{l}\text { Production } \\
\text { forest (HP), } \\
\text { protected forest } \\
(\mathrm{HL}) \text { and } \\
\text { Conservation } \\
\text { forest (HK) }\end{array}$ & $\begin{array}{l}\text { Outside of the } \\
\text { forest area }\end{array}$ \\
\hline $\begin{array}{l}\text { Managing } \\
\text { entities }\end{array}$ & $\begin{array}{l}\text { Farmer groups and } \\
\text { Cooperatives }\end{array}$ & Village institution & $\begin{array}{l}\text { Individual, } \\
\text { Farmer groups } \\
\text { and } \\
\text { Cooperatives }\end{array}$ & $\begin{array}{l}\text { Community and } \\
\text { forest } \\
\text { management }\end{array}$ & $\begin{array}{l}\text { Customary } \\
\text { communities }\end{array}$ \\
\hline Period & 35 years & 35 years & 35 years & $\begin{array}{l}\text { Based on } \\
\text { agreement, and } \\
5 \text { years for } \\
\text { conservation } \\
\text { partnership }\end{array}$ & Not specified \\
\hline $\begin{array}{l}\text { Forest } \\
\text { utilization }\end{array}$ & $\begin{array}{l}\text { Utilization of the } \\
\text { area, utilization of } \\
\text { environmental } \\
\text { services, } \\
\text { utilization/collecti } \\
\text { on of non-timber } \\
\text { forest products, } \\
\text { and } \\
\text { utilization/collecti } \\
\text { on of timber forest } \\
\text { products } \\
\text { (specifically for } \\
\text { production forest) }\end{array}$ & $\begin{array}{l}\text { Utilization of the } \\
\text { area, utilization of } \\
\text { environmental } \\
\text { services, } \\
\text { utilization/collecti } \\
\text { on of non-timber } \\
\text { forest products, } \\
\text { and } \\
\text { utilization/collecti } \\
\text { on of timber forest } \\
\text { products } \\
\text { (specifically for } \\
\text { production forest) }\end{array}$ & $\begin{array}{l}\text { Utilization of } \\
\text { timber forest } \\
\text { products }\end{array}$ & $\begin{array}{l}\text { Environmental } \\
\text { services, } \\
\text { utilization/colle } \\
\text { ction of non- } \\
\text { timber forest } \\
\text { products, and } \\
\text { utilization/colle } \\
\text { ction of timber } \\
\text { forest products } \\
\text { (specifically for } \\
\text { production } \\
\text { forest) }\end{array}$ & $\begin{array}{l}\text { Utilization of } \\
\text { genetic } \\
\text { resources, } \\
\text { utilization of } \\
\text { environmental } \\
\text { services, } \\
\text { utilization/colle } \\
\text { ction of non- } \\
\text { timber forest } \\
\text { products, and } \\
\text { utilization/colle } \\
\text { ction of timber } \\
\text { forest products }\end{array}$ \\
\hline
\end{tabular}

\subsection{The concept of $\mathrm{KPH}$}

The concept of KPH was introduced in 1999 with the enactment of Act No. 41 of 1999. KPH is defined as "the smallest forest management unit according to its main function and designation, which can be managed efficiently and sustainably, including protection of forest management units $(K P H L)$, production forest management units (KPHP), conservation forest management units (KPHK), community forest management units (KPHKM), customary forest management units (KPHA), and watershed management units (KPDAS)". Furthermore, in Government Regulation 6 of 2007, KPH is defined as "a forest management area in accordance with its main function and designation, which can be managed efficiently and sustainably". With this concept of KPH, all forest areas in Indonesia would be divided into KPH areas. In one area the KPH can consist of more than one main function of the forest whose name is determined by the function of the dominant forest area. KPHs are managed by government organizations that conduct forest management functions (Kartodihardjo et al., 2011). KPH are thus the building blocks of forestry development that seek to solve specific problems at the site level and can become enabling conditions for achieving sustainable forest management (Supratman, 2007; Setyarso et al., 2014). KPH serves to manage certain areas to realize

\footnotetext{
${ }^{3}$ KPHL or Kesatuan Pengelolaan Hutan Lindung, KPHP or Kesatuan Pengelolaan Hutan Produksi, KPHK or Kesatuan Pengelolaan Hutan Konservasi, KPHM or Kesatuan Pengelolaan Hutan Kemasyarakatan, KPHA or Kesatuan Pengelolaan Hutan Adat, KPDAS or Kesatuan Pengelolaan Daerah Aliran Sungai.
} 
a balance of economic, ecological and social functions (Hardjana, 2010; Djaenudin, 2014). With this mandate, KPH also has technical functions. For example, they are tasked with arranging forest management plans and forest utilization. KPH perform managerial functions such as planning, monitoring, evaluation, and outlining forestry policies, as well as conducting business functions such as encouraging investment in the region (Ekawati, 2014a).

In programmatic terms, besides having their own characteristics, KPH and SF also have several similarities (Figure 1). KPH and SF are forest management systems at the site level that aim for sustainability by striving for forest management through improved economic, ecological and social outcomes. These goals support a strategy for forest management for both SF and KPH pursued through area management, institutional management and business management (Hakim, 2010; Raharjo \& Ulifah, 2014).

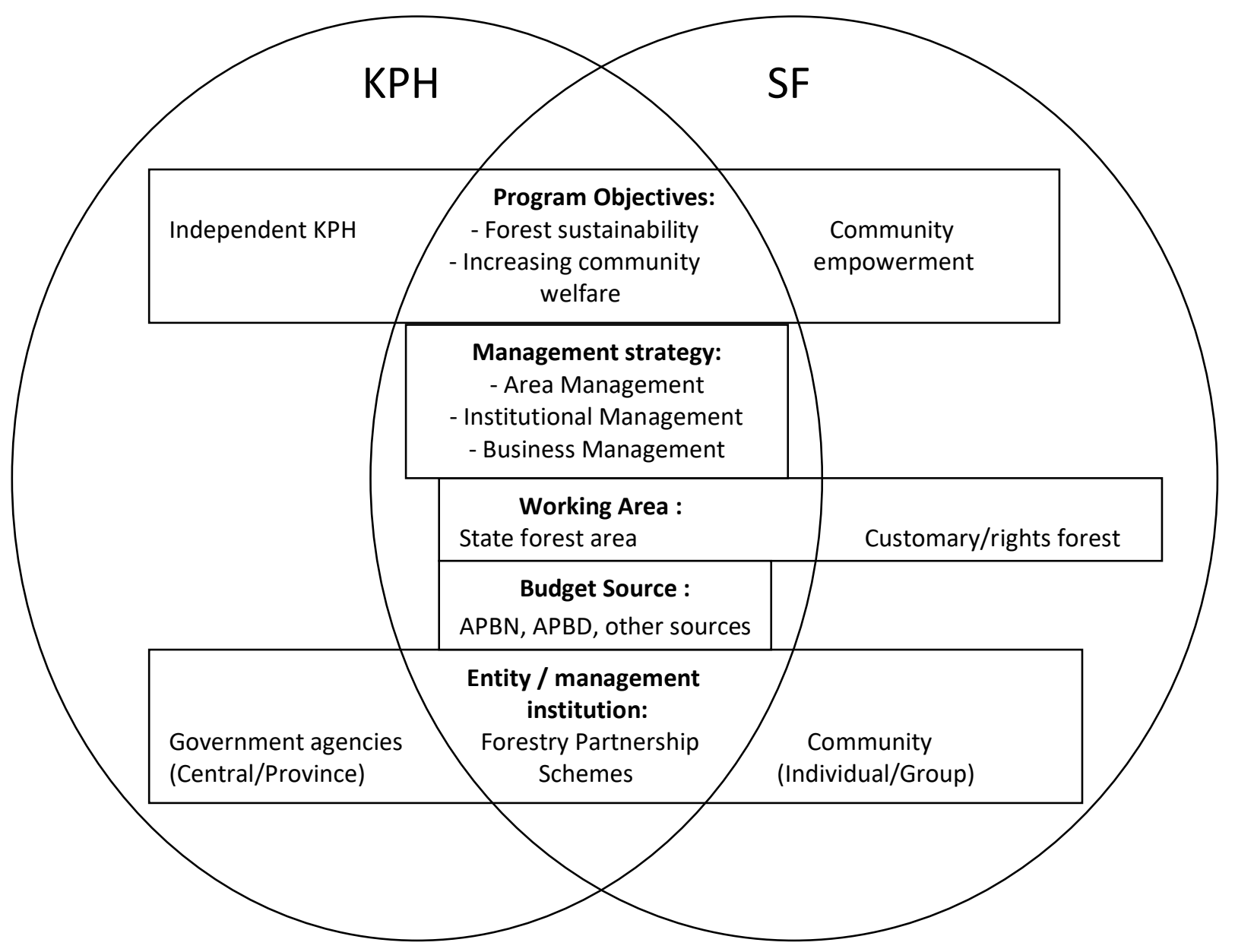

Figure 1. Characteristics and relationship between KPH and SF programs APBN : State Budget; APBD : Regional Revenue and Expenditure Budget

\section{Methods}

The theory of bureaucratic politics is used to analyze the policies and implementation of SF programs under the KPH system. Data was collected using four different methods, namely: content analysis of policy documents, semi-structured interviews, questionnaires and field observations.

1. The content analysis of the policy was used to analyze the most relevant and up-to-date policy documents to find out the formal structure and mandate of bureaucracies that deal with KPH 
and SF (following Sahide et al., 2016). The policy documents analyzed included: laws, government regulations, ministerial regulations and director general regulations. Various statements relevant to our research have been extracted to explain all aspects related to the $\mathrm{KPH}$ and SF program.

2. Semi-structured interviews were conducted from March 2017 to April 2018 with personnel from various government entities (MOEF, provincial government, $\mathrm{KPH}$ ), NGOs and communities that have obtained SF permits.

3. Questionnaires were delivered to KPH officials examined how forest management is carried out by $\mathrm{KPH}$ s and their role in developing SF programs. Selected respondents were structural officials at the KPH (generally the Chief of KPH) from 18 KPHs in South Sulawesi, West Sulawesi, Southeast Sulawesi and Central Sulawesi.

4. Field observations were conducted to examine the KPH and SF implementation programs in the field. Field observations were made during various implementation stages of KPH and SF programs in the regions of South Sulawesi, West Sulawesi and Southeast Sulawesi provinces.

\section{Results}

\subsection{The messy governance of KPH and SF: A bureaucratic politics perspective}

To support implementation of KPH and SF programs, MOEF established bureaucratic organizations at the central and regional levels, while the provincial government forms the Provincial Forestry Service and $\mathrm{KPH}^{4}$ at the provincial and site level (Figure 2). In terms of bureaucratic structure, $\mathrm{KPH}$ programs have more complete bureaucratic organizations all the way to the site level, whereas for SF, management structures only reach the regional level. Under these conditions, the implementation of SF programs in the field depends on KPH institutions as the only forestry institution at the site level.

Bureaucratic organizations at the central level generally have the authority to make regulations, establishing $\mathrm{KPH}$ and issuing SF permits, approving budget, and ratifying long-term forest management plans (RPHJP). ${ }^{5}$ At the regional level, there are the Technical Implementation Units (UPT) of MOEF, ${ }^{6}$ which generally have the authority for planning and managing the national budget, supervising and facilitating KPH and SF programs. Furthermore, at the provincial level, there is the Provincial Forestry Service that plays a role in the formation and submission of KPH institutions to MOEF, providing budget allocation, human resources, facilities and infrastructure for KPHs. At the site level, there are $\mathrm{KPH}$ institutions that perform forest administration and management functions.

\footnotetext{
${ }^{4}$ In this article does not include the KPHK which is the Technical Implementation Unit of MOEF

${ }^{5}$ RPHJP, or Rencana Pengelolaan Hutan Jangka Panjang

${ }^{6}$ There are including the Watershed Management and Protected Forest Agency or BPDAS HL and Production Forest Management Agency or BPHP)
} 


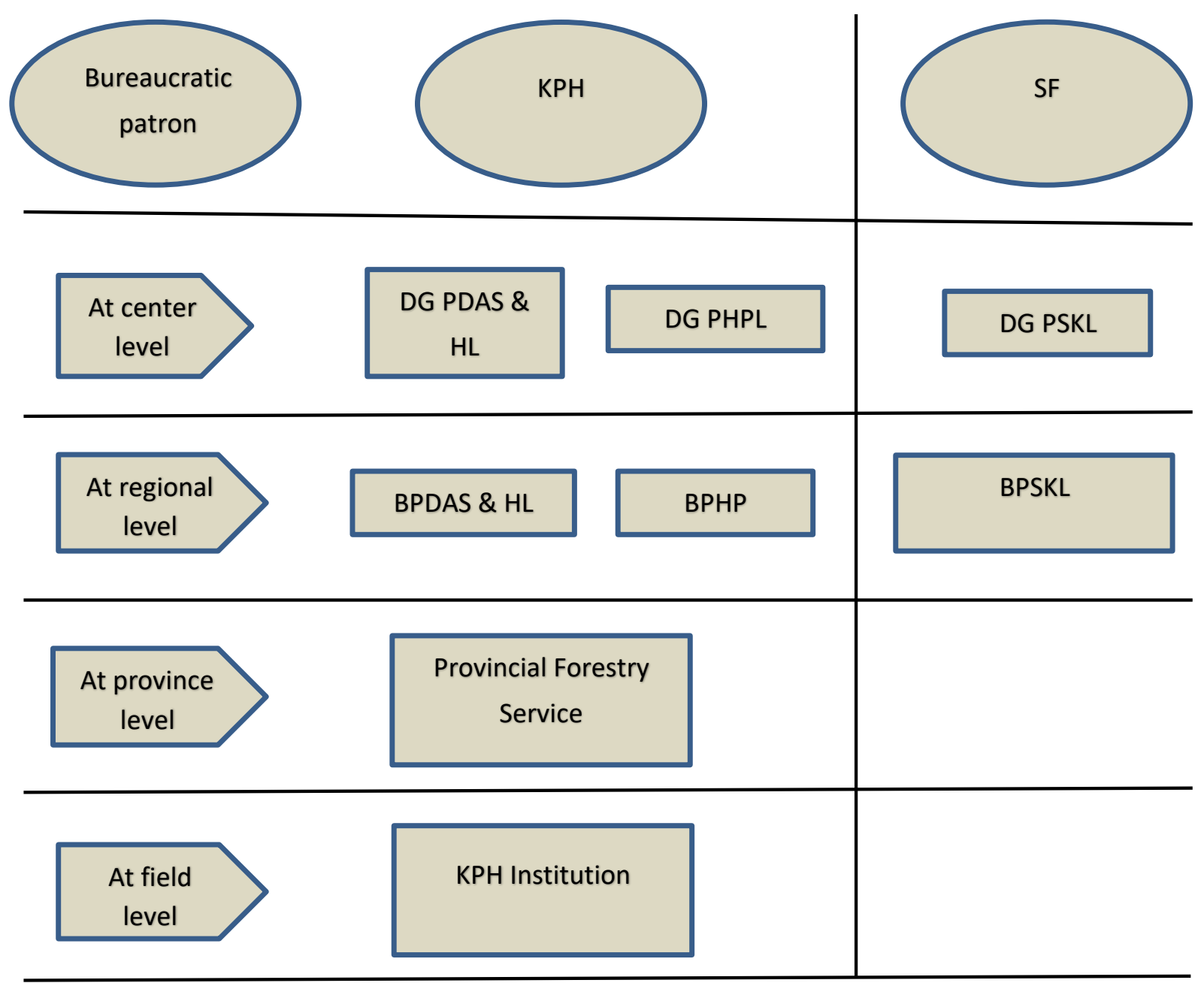

Figure 2. The bureaucratic patron of $\mathrm{KPH}$ and SF programs

DG PDAS \& HL: Directorate General of Watershed Management and Protected Forest,

DG PHPL: Directorate General of Sustainable Management of Production Forest, DG PSKL: Directorate General of Social Forestry and Environmental Partnership, BPSKL: Social Forestry and Environmental Partnership Agency

Various regulations have been issued to support the implementation of KPH and SF programs. However, regulations on the overall operationalization of $\mathrm{KPHs}$ have not yet been applied consistently. Amendments of Act No. 23 of 2014 has impacted KPH, especially in South Sulawesi Province. Several KPHs have been formed with the oversight of district governments, but which subsequently changed due to the Amendment of Act 23 by mandating the establishment of new institutions under the provincial government. Furthermore, independence in forest management is still an obstacle because of weak regulations governing $\mathrm{KPH}$ authority in the management and utilization of forest products in the region. The forestry partnership pattern is expected to be a means of KPH implementation but is still not feasible because of the strong dominance of the central government and the provincial forestry service in implementing cooperation agreements. Likewise, with the implementation of forest rehabilitation programming, which is one of the main tasks of the $\mathrm{KPH}$, interpretations of the regulations state that such functions are still under the authority of the central government.

Furthermore, KPH institutions - as the only bureaucratic organization at the site level - are 
expected to be able to support the realization of the SF program objectives. However, synchronization of regulations to support the development of SF and KPH programs are still lacking and proceeding in parallel, rather in coordination with one another. Although some regulations have regulated the role of $\mathrm{KPH}$ in the development of SF (Table 2), this role cannot be carried out maximally because of the limitations of $\mathrm{KPH}$ institutions.

Table 2. The roles of $\mathrm{KPH}$ in SF development

\begin{tabular}{|c|c|}
\hline Stage/SF Activities & The roles of $\mathrm{KPH}$ \\
\hline Identification of SF location & $\begin{array}{l}\text { 1. Identification of potential and conflict-prone } \\
\text { mapping in } \mathrm{KPH} \text { areas } \\
\text { 2. Identification and mapping of community rights } \\
\text { or claims in the } \mathrm{KPH} \text { area }\end{array}$ \\
\hline Reserve of SF area & $\begin{array}{l}\text { Determination of blocks for empowering } \\
\text { communities and certain regions }\end{array}$ \\
\hline Licensing process & $\begin{array}{l}\text { Part of the technical verification team requests the SF } \\
\text { scheme permit }\end{array}$ \\
\hline $\begin{array}{l}\text { Approval of } \mathrm{HD} / \mathrm{Hkm} \text { and } \mathrm{HTR} \\
\text { Management Plans }\end{array}$ & $\begin{array}{l}\text { 1. Forestry extension agent for RKU and } \mathrm{RKT}^{7} \text { in one } \\
\text { village } \\
\text { 2. Head of } \mathrm{KPH} \text { for permit cross-village work areas }\end{array}$ \\
\hline $\begin{array}{l}\text { Monitoring the SF scheme permit } \\
\text { activities }\end{array}$ & Monitoring for SF activities in the work area \\
\hline Partnership with the community & $\begin{array}{l}\text { KPHs can act as community partners in forest } \\
\text { management }\end{array}$ \\
\hline Mentoring & Providing extension agents as SF assistants \\
\hline Community empowerment & $\begin{array}{l}\text { 1. Conducting activities related to community } \\
\text { empowerment } \\
\text { 2. Business and community institutional } \\
\text { development with } \mathrm{KPH} \text { partners }\end{array}$ \\
\hline
\end{tabular}

On the other hand, the support of bureaucratic organizations on the development of SF is still weak. To encourage the development of the SF program, MOEF relies on BPSKL by providing a budget allocation that has continued to increase. However, the limited personnel available at BPSKL and the absence of institutions at the site level pose the main obstacles in its implementation. Technical staff at the PSKL in the Sulawesi region are limited compared to the extent of their work area responsibilities. The number of civil servants amount to only 57 people, assisted by 22 contract employees. With such a limited number of personnel, the hope of realizing the objectives of the SF program for such a vast geographic scope will be difficult to realize even though it is supported by a relatively large budget. The absence of organizations at the site level also resulted in protracted licensing processes in the reporting bureaucracy to the central level, resulting in a slow licensing process.

Furthermore, supporting the implementation of KPH and SF programs requires a substantial budget. From 18 sample KPH, budgeting still depends on state allocations (Table 3 ) with a small additional allocation for the SF program. Although there seems to be a substantial budget from several KPH for SF allocations, the budget is generally for the development of partnership programs between KPHs and the community, and does not include the SF permit category that follows the community partnership procedure as stipulated in MOEF regulation No. 83 of 2016.

The SF development budget depends on state budgets through the Director General of PSKL

${ }^{7}$ RKU : long term work plan (10 year), RKT : The annual work plan 
and BPSKL Region Sulawesi. Specifically, for the budget at the BPSKL Region Sulawesi, there is an increase in the budget for the period 2016-2018 (Figure 3). In addition to administrative operations, the budget is allocated for regional preparation activities and the development of business for SF and customary forests. Even though the budget looks large for a government agency at this scale, the vast working area covering 6 provinces or 81 districts / municipalities splinters the budget into small pieces.

Government policies in budgeting for KPH and SF programs also appear inconsistent. This is evident from the budget allocation from MOEF in 2019 allocated for forest rehabilitation activities. Even though this allocation indicates the notable importance of restoration activities and improving forest cover conditions, it also implies a significant reduction in the budgets for KPH and SF program implementation. An example is the budget for the operationalization of KPHP through BPHP Institution in Region-XIII Makassar, which in 2018 had a budget allocation for 12 KPHs, but in 2019 only allocated for $3 \mathrm{KPHs}$. This certainly has an impact on the low achievement of the program in the KPH including the development of SF.

Table 3. KPH's operational budget and budget allocation for SF

\begin{tabular}{|c|c|c|c|c|c|c|}
\hline \multirow{3}{*}{$\begin{array}{l}\text { Province and KPH } \\
\text { sample }\end{array}$} & \multicolumn{3}{|c|}{2017} & \multicolumn{3}{|c|}{2018} \\
\hline & \multicolumn{2}{|c|}{$\begin{array}{l}\text { KPH Budget } \\
\text { (in million) }\end{array}$} & \multirow{2}{*}{$\begin{array}{c}\text { Allocation } \\
\text { for SF (in } \\
\text { million) }\end{array}$} & \multicolumn{2}{|c|}{$\begin{array}{l}\text { KPH Budget } \\
\text { (in million) }\end{array}$} & \multirow[t]{2}{*}{$\begin{array}{l}\text { Allocation for S } \\
\text { (in million) }\end{array}$} \\
\hline & State Budget & $\begin{array}{l}\text { Regional } \\
\text { Budget }\end{array}$ & & $\begin{array}{l}\text { State } \\
\text { Budget }\end{array}$ & $\begin{array}{l}\text { Regional } \\
\text { Budget }\end{array}$ & \\
\hline $\begin{array}{l}\text { Southeast Sulawesi } \\
(8 \mathrm{KPH})\end{array}$ & 11.148 & 253 & 1.183 & 6.803 & 463 & 1.786 \\
\hline $\begin{array}{l}\text { South Sulawesi ( } 2 \\
\text { KPH) }\end{array}$ & - & - & - & - & - & - \\
\hline $\begin{array}{l}\text { West Sulawesi (3 } \\
\mathrm{KPH})\end{array}$ & 6.096 & 200 & 1.355 & 4.110 & 1.165 & 1.672 \\
\hline $\begin{array}{l}\text { Central Sulawesi (5 } \\
\mathrm{KPH})\end{array}$ & 7.797 & 4.334 & 256 & 5.961 & 7.344 & 171 \\
\hline
\end{tabular}

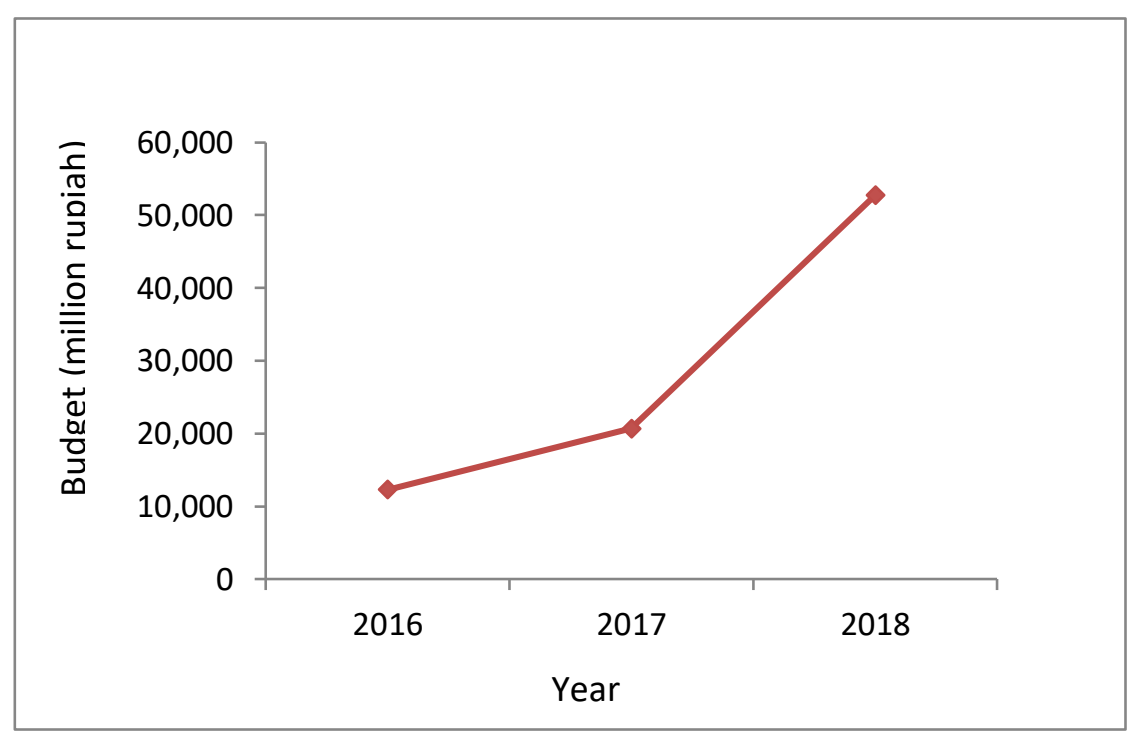

Figure 3. The BPSKL budget for Sulawesi in developing SF 


\subsection{SF practices in $\mathrm{KPH}$ areas}

Principally, the SF and KPH programs aim to improve community welfare and forest sustainability. Therefore, these two programs received strong support and commitment from policymakers and are used as priority programs in forest management in Indonesia. Furthermore, the implementation of the SF program cannot be separated from the KPH bureaucracy because the working area of SF in the forest area is in the working area of KPH either zoned in the empowerment blocks or in other area (Figure 4). Given these spatial overlapping conditions, the success of SF program are contingent upon the role of the $\mathrm{KPH}$.

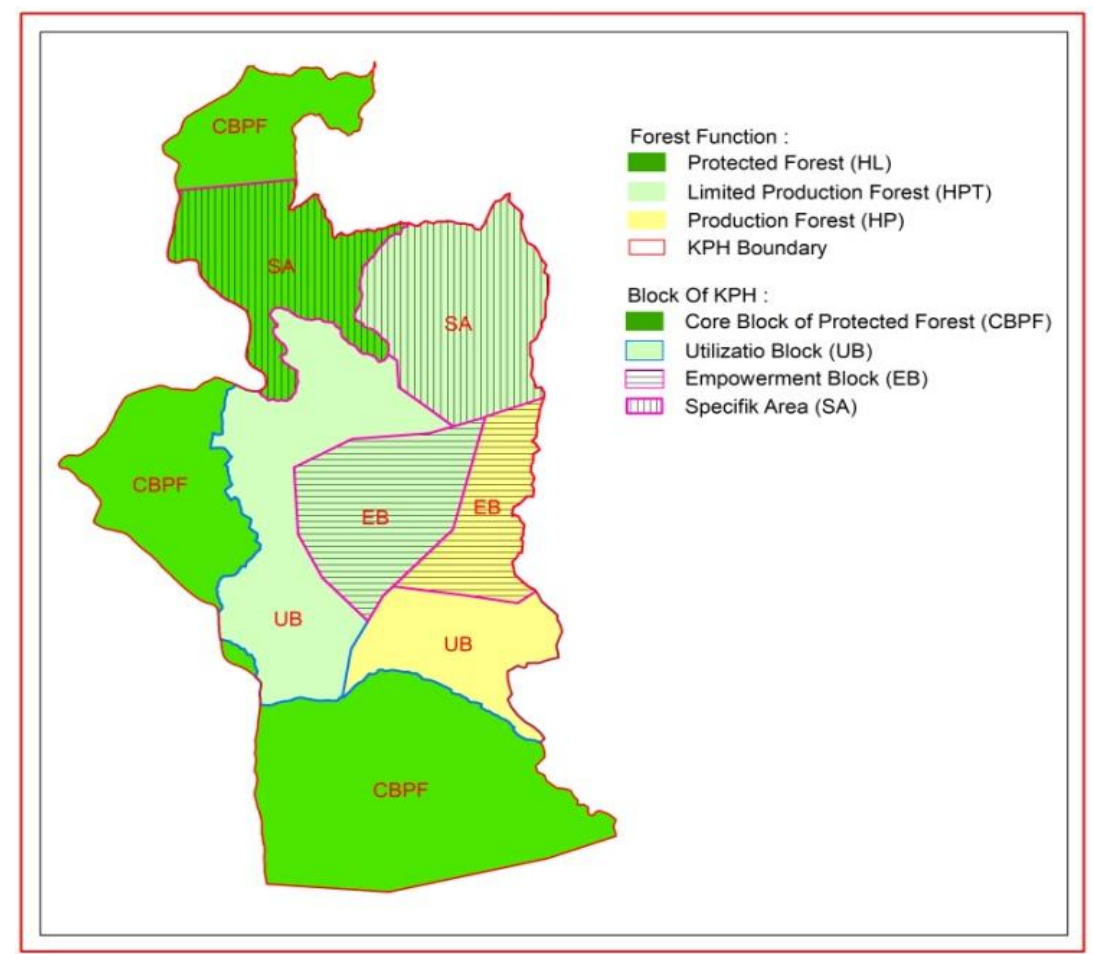

Figure 4. Illustration of zoning blocks and locations of SF permits in $\mathrm{KPH}$ areas

Until 2018, the role of the KPH in the development of SF was envisioned to facilitate the increased issuance of SF permits in the KPH area (Table 4). Increasing permits, especially in the HKm and Village Forest schemes, from across $18 \mathrm{KPHs}$ among the research samples highlighted that several KPH did not yet have SF scheme permits in their areas. From the various $\mathrm{KPH}$ roles, increasing the realization of SF programs in the field have continued to present challenges. Aside from budget constraints, the challenges to the development of SF schemes in KPH areas include:

1) the low capacity of human resources in KPHs to support SF development. Extension agents are not evenly distributed across $\mathrm{KPH}$ areas and some $\mathrm{KPH}$ do not yet have extension agents (see Table 4). In addition, extension agents in the KPH have previously served in the Executive Agency of Extension Agriculture, Fisheries and Forestry (BP4K). Furthermore, they are rarely involved with activities in forestry so that they are weak in their technical understanding of forestry.

2) The existence of $\mathrm{KPH}$ interests in realizing independence makes them selective in determining SF schemes they are willing to support. In this case, most KPHs tend to favor the forestry partnership schemes because the role of the $\mathrm{KPH}$ is greater and there are also opportunities to benefit from profit sharing. 
Table 4. Progress of issuance of SF scheme permits

\begin{tabular}{|c|c|c|c|c|c|c|c|c|c|c|c|c|c|c|c|c|c|}
\hline \multirow{3}{*}{ Province } & \multicolumn{8}{|c|}{ Before KPH (District Forestry Office) } & \multicolumn{8}{|c|}{ After $\mathrm{KPH}$} & \multirow{3}{*}{$\begin{array}{c}\text { Total } \\
\text { forestry } \\
\text { extension } \\
\text { officer }\end{array}$} \\
\hline & \multicolumn{2}{|c|}{$\mathrm{HKm}$} & \multicolumn{2}{|c|}{ HD } & \multicolumn{2}{|c|}{ HTR } & \multicolumn{2}{|c|}{$\begin{array}{c}\text { Partner } \\
\text { ship }\end{array}$} & \multicolumn{2}{|c|}{$\mathrm{HKm}$} & \multicolumn{2}{|c|}{ HD } & \multicolumn{2}{|c|}{ HTR } & \multicolumn{2}{|c|}{$\begin{array}{c}\text { Partner } \\
\text { ship }\end{array}$} & \\
\hline & $\begin{array}{l}\text { Per } \\
\text { mit }\end{array}$ & Area & $\begin{array}{l}\text { Per } \\
\text { mit }\end{array}$ & Area & $\begin{array}{l}\text { Per } \\
\text { mit }\end{array}$ & Area & $\begin{array}{l}\text { Per } \\
\text { mit }\end{array}$ & Area & $\begin{array}{l}\text { Per } \\
\text { mit }\end{array}$ & Area & $\begin{array}{l}\text { Per } \\
\text { mit }\end{array}$ & Area & $\begin{array}{l}\text { Per } \\
\text { mit }\end{array}$ & Area & $\begin{array}{l}\text { Per } \\
\text { mit }\end{array}$ & Area & \\
\hline $\begin{array}{c}\text { Southeast } \\
\text { Sulawesi } \\
(8 \mathrm{KPH})\end{array}$ & - & - & - & - & 12 & 5.140 & - & - & 3 & 1.110 & - & - & 3 & 1.817 & - & - & 50 \\
\hline $\begin{array}{c}\text { South } \\
\text { Sulawesi } \\
(2 \mathrm{KPH})\end{array}$ & 35 & 9.652 & 13 & 7.425 & 7 & 1.369 & - & - & 8 & 3.015 & 25 & 7.666 & - & - & - & - & 21 \\
\hline $\begin{array}{c}\text { West } \\
\text { Sulawesi } \\
(3 \mathrm{KPH})\end{array}$ & - & - & - & - & - & - & - & - & - & - & - & - & - & - & - & - & 3 \\
\hline $\begin{array}{c}\text { Central } \\
\text { Sulawesi } \\
\text { (5 KPH) }\end{array}$ & - & - & - & - & - & - & - & - & 19 & 9.289 & 24 & 16.421 & - & - & - & - & 35 \\
\hline
\end{tabular}

On the other hand, the low realization of SF programs in the field has made this program unable to provide significant contributions to the achievement of KPH objectives. As SF is also envisioned to support conflict resolution goals on state forest lands, the application of such roles among the KPH are still limited. In addition, the existence of the SF program is still perceived as a rival to the $\mathrm{KPH}$ in the management of forest areas. This perception emerged due to the limited role of the KPH in the management of the SF program area and the absence of direct income contributions to the $\mathrm{KPH}$.

\section{Discussion}

\subsection{Bureaucratic patron}

The policy of establishing KPH organizations is inseparable from the development of SF in the field. The existence of KPHs allows identification of land rights in forest areas and supports the needs of rural populations. Permits and collaborations are more likely to achieve regulations that provide support for community rights and access to forest resources in the long term (Kartodihardjo et al., 2011). However, the messiness of KPH governance has impacted the low realization rates and has also impacted the ability to achieve SF program objectives in the field.

Institutional strengthening needs to be pursued to support extensive forest management and to provide opportunities for greater access for intended parties (Kartodihardjo, 2006). This shows the importance of the bureaucratic structure of a program to reach the site level. It is unfortunate 
that the implementation of SF programs are not equipped with a bureaucratic structure to the site level and depends on the role of KPH institutions. However, this has become a separate problem because in the regulations relating to KPH institutions, SF programs are not clearly stated as one of the main tasks and functions of KPHs. Therefore, although the SF and KPH bureaucratic structures are different, the people who become clients are sometimes the same, resulting in conflicts or competition between bureaucracies (Sahide \& Giessen, 2015). In addition, although the central government perspective is that SF is a priority program, local governments tend to considers the forestry sector as a ancillary program, so that there is an imbalance in motivation between the central and regional governments in the development of SF (Suhirman et al., 2012).

Furthermore, KPH institutions themselves are still in the early stages of development and faced with regulations that have not fully supported KPH operations (Ekawati, 2014b; Fisher et al., 2017). The existing regulations still indicate the weak position of $\mathrm{KPH}$ in forest management, and the strong influence of the provincial forestry service and the central government. This is evident in regulations related to forestry partnerships, forest rehabilitation and budgeting. The results of Sahide et al. (2016) illustrate how the central government through KPH and SF is in the process of regaining its authority for forest administration and management, what they describe as a recentralization strategy. Therefore, the government should revise several regulations to support KPH in the development of SF, among others, regulations related to the role of $\mathrm{KPH}$ in the development of $\mathrm{HKm}$, HTR and Village Forests (Ekawati, 2014b).

On the other hand, these messy governance conditions also affect regulations related to the development of SF. In general, regulations still embody top-down policies (Gelo \& Koch, 2012; Hajjar et al., 2013) and centralized management practices (Jusuf \& Fahrul, 2011; Schusser, 2013) so that they have an impact on field conditions that cannot adequately respond to local needs. For example, licensing regulations that are long and complex have implications for the slow process of issuing SF scheme permits (Rahmina, 2011; Muhajir et al., 2011; Wiratno, 2014; Praputra et al., 2015). Therefore, the delegation of SF implementation to the site level through KPH oversight is also supported with budgets and capacity building that can help to address existing implementation conditions (Herawati et al., 2017).

\subsection{Budget politics}

Success of KPH and SF implementation programs is largely determined by the central or regional government budget allocation. KPHs, though assigned formally to oversee site level implementation in forest management still faces budget problems. The system implemented by MOEF regulates operational budgeting for KPHLs through the Director General of PDAS HL, while for $\mathrm{KPHP}$, it is conducted through the Director General of PHPL. However, the inconsistency of budget allocation from the central government by increasing the rehabilitation budget has resulted in reduced budget allocations for $\mathrm{KPH}$ operations. As a result, many KPHs do not receive operational budget allocations from the central government. The budget allocation from the local government also turns out to be very limited and does not fully support the operation of the KPH (Suryandari \& Alviya, 2009).

Furthermore, the budget for SF development comes directly from the ministry or in coordination with BPSKL, while KPHs face budget constraints and do not receive special budget allocation to support SF. This condition shows the low commitment of the government in budget allocation for the development of SF through the site level management systems (Agbogidi et al., 2007; Suhirman et al., 2012) impacting the role that KPH can play in supporting SF. An example is the lack of a budget for forestry extension agents budgeted by BPSKL. This has an impact on the low quality of community assistance and administrative services by forestry extension agents. The development of SF is therefore dependent on, and inseparable from the role of forestry extension agents (Falconer, 1987; Gautam, 1999). 


\subsection{Bureaucratic preferences}

The central challenge in the development of SF is how the program can support the objectives of the $\mathrm{KPH}$, especially in realizing the independence of the $\mathrm{KPH}$. The strong demand to realize independence in forest management (Subarudi, 2014) makes KPH selective in the type of SF scheme, preferring a specific type over others. In most cases KPH tend to prefer forestry partnership schemes compared to other SF schemes because of the possibility of profit-sharing. The position of SF permits is principally the same as other permits, so that the requirements and procedures for implementing the program tend to be equated with a large-scale permit. Whereas the SF scheme permit holders are often people from rural areas who have low formal capital and capacity (financial, institutional, physical, human, social), implementation thus requires facilitation by government and other partners to support managing land blocks and facilitate larger-scale business ventures (Setyarso et al., 2014).

On the other hand, the government bureaucracy responsible for the implementation of the SF program continues to struggle to develop SF schemes other than the forestry partnership scheme. Efforts are supported by the characteristics and desires of people who sometimes want to be independent in implementing the SF program. This is still a problem because of the strength of the $\mathrm{KPH}$ bureaucracy in blocking the development of SF schemes. These conditions thus show that the state bureaucracy still views increasing authority as the main goal of the organization, ignoring their broader responsibility for managing forest resources for the welfare of communities (Poffenberger, 1990). Therefore, the government must issue and refine regulations related to the implementation of the SF scheme to be flexible in accordance with field conditions that are easy enough to implement (Sumanto, 2009). These must be in sync with regulations related to KPH policies, because in the context of KPHs that directly interact with the operationalization of various SF schemes, the responsibility for their success requires detailed roles that can be performed by the KPH (Setyarso et al., 2014).

\section{Conclusions}

Supporting bureaucratic structures that reach the field site is a major obstacle in the development of the SF program. The implementation of SF depends on the role of KPH institutions that have a bureaucratic structure to the site level. However, SF programs are not clearly stated as one of the main tasks and functions of KPHs. The weakness of KPH institutions and independence caused by the strong influence of the central government and provincial forestry service, as well as the absence of special budget allocations for SF development in KPH, has influenced the role of the $\mathrm{KPH}$ in providing optimal support to the development of SF programs. In addition, KPH interests to create independence makes the KPH selective towards particular SF schemes (the forestry partnership scheme) that offer profit sharing and do not necessarily always keep in mind the broader goals of SF.

On the other hand, bureaucratic organizations with a mandate for SF have not always involved $\mathrm{KPH}$ institutions. Budget structures and allocations clearly attest to this point. The budget for SF comes from parallel and uncoordinated ways from the Directorate General of PSKL and the BPSKL. Even though SF management structures have limited personnel, there was no visible commitment and willingness from MOEF to distribute SF development budgets to KPH institutions. In addition, the regulations governing SF programs still appear rigid and difficult to apply, showing the dominant authority and administrative control of the central government.

This overall contrast of policy imaginary and implementation reality indicates that the formal objectives of SF and KPH policies are not always in accordance with the informal objectives of the bureaucratic organizational authority (Sahide et al., 2016). Different interests of bureaucratic organizations indicate that they informally push for their survival and expansion (Giessen et al., 2014). With the competitive and adversarial conditions, the hopes of realizing the broader goals of 
$\mathrm{KPH}$ and SF programs will be difficult to realize. Therefore, efforts to review and refine various regulations to synchronize SF and $\mathrm{KPH}$ policies become an urgent need to be performed (Setyarso et al., 2014; Ekawati, 2014b).

Conflicts of Interest: The authors declare no conflict of interest. The founding sponsors had no role in the design of the study; in the collection, analyses, or interpretation of data; in the writing of the manuscript, and in the decision to publish the results.

Acknowledgement: We are grateful to the Ministry of Environment and Forestry for funding this research through the Center of Forestry and Environment Education, Training, and Human Resources Development, and all persons who have helped in conducting this research.

\section{Reference}

Agbogidi, O. M., Ofuoku, A. U., \& Dolor, D. E. (2007). Role of community Forestry in sustainable forest Management and Development: a Review. ASSET : An International Journal (Series A)\}, 7(1), 44-54. Retrieved from http://journal.unaab.edu.ng/index.php/Series_A/article/view/6

Baynes, J., Herbohn, J., \& Dressler, W. (2016). Power relationships: Their effect on the governance of community forestry in the Philippines. Land Use Policy, 54, 169-176. doi: https://doi.org/10.1016/j.landusepol.2016.01.008

Cooter, R. D. (1994). Structural adjudication and the new law merchant: A model of decentralized law. International Review of Law and Economics, 14(2), 215-231. doi: https://doi.org/10.1016/0144-8188(94)90020-5

Cronkleton, P., Larson, A. M., Feintrenie, L., Garcia, C., \& Levang, P. (2013). Reframing Community Forestry to Manage the Forest-Farm Interface. Small-Scale Forestry, 12(1), 5-13. doi:https://doi.org/10.1007/s11842-012-9229-8

Das, C. R. (2015). Social Forestry in Odisha : An Extraordinary International Aided Initiative Towards Revival and Restoration of Forests . International Journal of Research and Development - $A$ Management Review (IJRDMR), 4(2), 28-49.

Diefenbach, T., \& Sillince, J. A. A. (2015). Formal and Informal Hierarchy in Different Types of Organization. Organization Studies, 32(11), 1515-1537. doi: https://doi.org/10.1177/0170840611421254

Djaenudin, D. (2014). Kelayakan Ekonomi Usaha Jasa Lingkungan di KPHL Pohuwatu, Provinsi Gorontalo pp 101-124. In: Ekawati, S., Hernowo, B. (Eds). Operasionalisasi Kesatuan Pengelolaan Hutan (KPH): Langkah Awal Menuju Kemandirian. Sleman: PT. Kanisius.

Dupuits, E. (2014). Transnational self-help networks and community forestry: A theoretical framework. Forest Policy and Economics, 58, 5-11. doi: https://doi.org/10.1016/j.forpol.2014.07.007

Edmunds, D., Wollenberg, E., Contreras, A. P., Dachang, L., Kelkar, G., Nathan, D., ... Singh, N. M. (2003). Local Forest Management: The Impacts of Devolution Policies. (D. Edmunds \& E. Wollenberg, Eds.). Center for International Forestry Research (CIFOR).

Ekawati, S. (2014a). Apakah yang dimaksud dengan Kesatuan Pengelolaan Hutan (KPH)? pp 1-20. In Ekawati, S., Hernowo, B. (Eds). Operasionalisasi Kesatuan Pengelolaan Hutan (KPH): Langkah Awal Menuju Kemandirian. Sleman: PT. Kanisius.

Ekawati, S. (2014b). Terobosan Penting Melembagakan KPH Dalam Pengelolaan Hutan di Indonesia pp 39-68. In : Ekawati, S., Hernowo, B. (Eds). Operasionalisasi Kesatuan Pengelolaan Hutan (KPH): Langkah Awal Menuju Kemandirian. Sleman: PT. Kanisius.

Falconer, J. (1987). Forestry Extension: a Review of The Key Issues. Social Forestry Network, 1-34.

Fisher, L. A., Kim, Y.-S., Latifah, S., \& Mukarom, M. (2017). Managing Forest Conflicts: Perspectives of Indonesia's Forest Management Unit Directors. Forest and Society, 1(1). doi: 
https://doi.org/10.24259/fs.v1i1.772

Fisher, R. J. (1999). Devolution and decentralization of forest management in Asia and the Pacific. Unasylva, 50(4): 3-5.

Gautam, K. H. (1999). Approach to extension in Forestry : experience of community forestry in Nepal. Banko Janakari, 9(1), 29-32.

Gelo, D., \& Koch, S. F. (2012). Does one size fit all? Heterogeneity in the valuation of community forestry programs. Ecological Economics, 74, 85-94. doi: https://doi.org/10.1016/j.ecolecon.2011.11.010

Giessen, L., Krott, M., \& Möllmann, T. (2014). Forest Policy and Economics Increasing representation of states by utilitarian as compared to environmental bureaucracies in international forest and forest - environmental policy negotiations. Forest Policy and Economics, 38, 97-104. doi: https://doi.org/10.1016/j.forpol.2013.08.008

Gilmour, D. (2016). Forty years of community-based forestry: A review of its extent and effectiveness. Rome: Food and Agriculture Organizations of the United Nations.

Hajjar, R., McGrath, D. G., Kozak, R. A., \& Innes, J. L. (2013). Framing community forestry challenges with a broader lens: Case studies from the Brazilian Amazon. Journal of Environmental Management, 92(9), 2159-2169. doi:https://doi.org/10.1016/j.jenvman.2011.03.042

Hakim, I. (2010). Orientasi Makro Kebijakan Social Forestry di Indonesia pp 1-32 dalam : S. Anwar dan I. Hakim (Ed.). Menuju Restorasi Pembangunan Kehutanan Berkelanjutan.

Hardjana, A. K. (2010). Desentralisasi kehutanan dalam terwujudnya pembentukan KPH. Info Teknis Dipterokarpa, 4(1).

Herawati, T., Liswanti, N., \& Banjade, M. R. (2017). Merancang Masa Depan Perhutanan Sosial di Provinsi Lampung : Dari skenario menuju aksi. Brief Cifor, (183), 1-8. doi:https://doi.org/10.17528/cifor/006558

Hjern, B., \& Hull, C. (1982). Implementation Research as Empirical Constitutionalism. European Journal of Political Research, 10(2), 105-115. doi:https://doi.org/10.1111/j.14756765.1982.tb00011.x

Hubo, C., \& Krott, M. (2010). Politiksektoren als Determinanten von Umweltkonflikten am Beispiel invasiver gebietsfremder Arten. Umwelt- Und Technikkonflikte, 219-238. doi:https://doi.org/10.1007/978-3-531-92354-3_11

Jusuf, Y., \& Fahrul, F. (2011). Analisis performasi kelembagaan kehutanan pada masa otonomi daerah (otoda) di Kabupaten Gowa, Takalar dan Jeneponto. Jurnal Hutan dan Masyarakat, 6(1), 31-42.

Kartodihardjo, H. (2006). Masalah Kapasitas Kelembagaan dan Arah Kebijakan Kehutanan: Studi Tiga Kasus. Jurnal Manajemen Hutan Tropika, 12(3), 14-25.

Kartodihardjo, H., Nugroho, B., \& Putro, H. R. (2011). Pembangunan Kesatuan Pengelolaan Hutan (KPH) - Konsep, Peraturan Perundangan dan Implementasi. Direktorat Wilayah Pengelolaan dan Penyiapan Areal Pemanfaatan Kawasan Hutan, Direktur Jenderal Planologi Kehutanan.

Kartodihardjo, H., Nugroho, B., \& Suharjito, D. (2013). Development of Small Holder Plantation Forests: An Analysis from Policy Process Perspective. Jurnal Manajemen Hutan Tropika (Journal of Tropical Forest Management), 19(2), 111-118. doi: https://doi.org/10.7226/jtfm.19.2.111

Kartodiharjo, H., \& Suwarno, E. (2014). Pengarusutamaan Kesatuan Pengelolaan Hutan ( KPH ) dalam Kebijakan dan Pelaksanaan Perizinan Kehutanan Pengarusutamaan Kesatuan Pengelolaan Hutan ( KPH ) Kebijakan dan Pelaksanaan Perizinan Kehutanan. Jakarta (ID): Direktorat Wilayah Pengelolaan dan Penyiapan Areal Pemanfaatan Kawasan Hutan Direktorat Jenderal Planologi Kehutanan.

Krott, M. (2005). Forest Policy Analysis (translated by Renée von Paschen). Springer Publications.

Maryudi, A., Citraningtyas, E. R., Purwanto, R. H., Sadono, R., Suryanto, P., Riyanto, S., \& Siswoko, B. D. (2015). The emerging power of peasant farmers in the tenurial conflicts over the uses of 
state forestland in Central Java, Indonesia. Forest Policy and Economics, 67(OCTOBER), 7075. doi: https://doi.org/10.1016/j.forpol.2015.09.005

Maryudi, A., Devkota, R. R., Schusser, C., Yufanyi, C., Salla, M., Aurenhammer, H., ... Krott, M. (2012). Back to basics: Considerations in evaluating the outcomes of community forestry. Forest Policy and Economics, 14(1), 1-5. doi: https://doi.org/10.1016/j.forpol.2011.07.017

Moktan, M. R., Norbu, L., \& Choden, K. (2016). Can community forestry contribute to household income and sustainable forestry practices in rural area? A case study from Tshapey and Zariphensum in Bhutan. Forest Policy and Economics, 62, 149-157. doi:https://doi.org/10.1016/j.forpol.2015.08.011

Muhajir, M., Arizona, Y., Firdaus, A. Y., \& Safitri, M. A. (2011). Arah Reformasi Kebijakan Penguasaan Kawasan Hutan di Indonesia. Kertas Kerja Epistema No.02/2011, Jakarta: Epistema Institute.

Ostrom, E. (2005). Understanding Institutional Diversity. Understanding Institutional Diversity. New Jersey: Princeton University Press. doi: https://doi.org/10.1007/s11127-007-9157-x

Poffenberger M. (Ed.). (1990). Keepers of the Forest: Land ManagementAlternatives in Southeast Asia. West Hartford: Kumarian Press.

Praputra, A. V., Sahide, M. A. K., \& Santosa, A. (2015). Menata Era Baru Kehutanan Masyarakat. Policy Brief. Forum Komunikasi Kehutanan Masyarakat. Bogor. doi: https://doi.org/10.13140/RG.2.1.4587.8249

Preston, T., \& 'T Hart, P. (1999). Understanding and evaluating bureaucratic politics: The nexus between political leaders and advisory systems. Political Psychology, 20(1), 49-98. doi:https://doi.org/10.1111/0162-895X.00137

Raharjo, K. D., \& Ulifah, C. N. (2014). Struktur Organisasi dan Sumberdaya Manusia pada KPHP: Pembelajaran dari Perum Perhutani pp 125-180. In: Ekawati, S., Hernowo, B. (Eds). Operasionalisasi Kesatuan Pengelolaan Hutan (KPH): Langkah Awal Menuju Kemandirian. Sleman: PT. Kanisius.

Rahmina. (2011). Pilihan Skema Pengelolaan Hutan Berbasis Masyarakat dalam Mitigasi Perubahan Iklim. Deutsche Gesellschaft für Internationale Zusammenarbeit (GIZ) GmbH-Forests and Climate Change Programme (FORCLIME).

Rizal, A., Dewi, I. N., \& Kusumedi, P. (2011). Kajian Strategi Implementasi Kesatuan Pengelolaan Hutan ( KPH ): Studi Kasus di Kabupaten Tana Toraja. Jurnal Analisis Kebijakan Kehutanan, 8(2), 167-188.

Sahide, M. A. K., \& Giessen, L. (2015). Land Use Policy The fragmented land use administration in Indonesia - Analysing bureaucratic responsibilities influencing tropical rainforest transformation systems. Land Use Policy, 43, 96-110. doi:https://doi.org/10.1016/j.landusepol.2014.11.005.

Sahide, M. A. K., Maryudi, A., Supratman, S., \& Giessen, L. (2016). Is Indonesia utilising its international partners? The driving forces behind Forest Management Units. Forest Policy and Economics, 69, 11-20. doi: https://doi.org/10.1016/j.forpol.2016.04.002.

Sahide, M. A. K., Supratman, S., Maryudi, A., Kim, Y. ., \& Giessen, L. (2016). Decentralisation policy as recentralisation strategy: forest management units and community forestry in Indonesia. International Forestry Review, 18(1), 78-95. doi: https://doi.org/10.1505/146554816818206168

Schusser, C. (2013). Who determines biodiversity? An analysis of actors' power and interests in community forestry in Namibia. Forest Policy and Economics, 36, 42-51. doi:https://doi.org/10.1016/j.forpol.2012.06.005

Schusser, C., Krott, M., Movuh, M. C. Y., Logmani, J., Devkota, R. R., Maryudi, A., \& Salla, M. (2014). Comparing community forestry actors in Cameroon, Indonesia, Namibia, Nepal and Germany. Forest Policy and Economics, 1-7. doi:https://doi.org/10.1016/j.forpol.2016.03.001

Setyarso, A., Djajono, A., Nugroho, B., Wulandari, C., Suwarno, E., Kartodihardjo, H., \& Sardjono, M. A. (2014). Strategi Pengembangan KPH dan Perubahan Struktur Kehutanan Indonesia. 
Direktorat Jenderal Planologi Kehutanan.

Soepijanto, B., Zauhar, S., Haryono, B. S., \& Soeaidy, S. (2013). Model of Effective Community Empowerment Policy of Forestry Partnership to Forest Community in Mesuji-Lampung, 17(1), 7-14.

Subarudi. (2014). Pengelolaan Wisata Alam Menuju Kemandirian KPH pp 201-228. In : Ekawati, S., Hernowo, B. (Eds). Operasionalisasi Kesatuan Pengelolaan Hutan (KPH): Langkah Awal Menuju Kemandirian. Sleman: PT. Kanisius.

Suharjito, D. (2009). Devolusi Pengelolaan Hutan di Indonesia: Perbandingan Indonesia dan Philipina (Devolution of Forest Management in Indonesia : Comparison between Indonesia and Philipina). Jmht, XV(3), 123-130.

Suhirman, Alamsyah, Z., Zaini, A., Sulaiman, \& Nikoyan, A. (2012). Studi Perencanaan \& Penganggaran bagi Pengelolaan Hutan berbasis Masyarakat di Indonesia. Jakarta: Kemitraan.

Sumanto, S. E. (2009). Kebijakan Pengembangan Perhutanan Sosial dalam Perspektif Resolusi Konflik. Jurnal Analisis Kebijakan Kehutanan, 6(1), 13-25.

Supratman. (2007). Desain Model Pembangunan Kesatuan Pengelolaan Hutan (KPH) di Kabupaten Mamuju Provinsi Sulawesi Barat. Jurnal Perennial, 5(1) : 36-44.

Suryandari, E. Y., \& Alviya, I. (2009). Implementation and Strategy of Banjar Forest Mangement Unit Development. Jurnal Analisis Kebijakan Kehutanan, 6(1), 57-70. Retrieved from http://ejournal.forda-mof.org/ejournal-litbang/index.php/JAKK/article/view/341

Suwarno, E., Ratnaningsih, A. T., \& Insusanty, E. (2016). Implikasi Terbitnya Undang-Undang Nomor 23 Tahun 2014 Terhadap Pembangunan Kesatuan Pengelolaan Hutan Di Provinsi Riau. Wahana Forestra: Jurnal Kehutanan, 11(1), 9-21.

Thompson, H. (1999). Social forestry: An analysis of Indonesian forestry policy. Journal of Contemporary Asia, 29(2), 187-201. https://doi.org/10.1080/00472339980000311

Wiratno. (2014). Hutan Kemasyarakatan dan Hutan Desa Sebagai Solusi Konflik Pengelolaan Hutan serta Penyelamatan Habitat dan Perlindungan Keragaman Hayati pp. 73-85 dalam : I. Hakim dan L.R. Wibowo (Ed.). Hutan Untuk Rakyat : Jalan Terjal Reforma Agraria di Sektor Kehutan, LKiS Yogya.

Wittrock, B., Lindström, S., \& Zetterberg, K. (1982). Implementation Beyond Hierarchy: Swedish Energy Research Policy. European Journal of Political Research, 10(2), 131-143. https://doi.org/10.1111/j.1475-6765.1982.tb00013.x

Yasmi, Y. (2008). Peningkatan Konflik dalam Pengelolaan Sumberdaya Hutan pp. 287-298 dalam : H. Adnan, D. Tadjudin, E.L. Yuliani, H. Komarudin, D. Lopulalan, Y. L. Siagian dan D.W. Munggoro (Ed.). Belajar dari Bungo: Mengelola Sumberdaya Alam di Era Desentralisasi. Center for International Forestry Research (CIFOR).

\section{Regulations Materials}

Law 41 of 1999 on Forestry. Undang-Undang Nomor : 41 Tahun 1999 tentang kehutanan

Law 23 of 2014 on Local government. Undang-Undang Nomor : 23 Tahun 2014 tentang pemerintahan daerah.

Government Regulation 6 of 2007 on forest governance and forest management planning and forest utilization. Peraturan Pemerintah Nomor : 6 Tahun 2007 tentang tata hutan dan penyusunan rencana pengelolaan hutan, serta pemanfaatan hutan

MOEF Regulation P.83 of 2016 on Social Forestry. Peraturan Menteri Lingkungan Hidup dan Kehutanan Nomor : P.83/Menlhk/Setjen/Kum.1/10/2016 tentang perhutanan sosial. 